УДК 821.163.41.8 Јанковић Е. 811.163.41-26"17"

https://doi.org/10.18485/msc50.2021.2.ch19

\title{
Питер Херити
}

\section{ЈЕЗИК ЕМАНУИЛА ЈАНКОВИЋА}

Чини ми посебно задовољство да овде у Новом Саду имам прилику говорити о језику Новосађанина који је био без сумње један од најистакнутијих и најпрогресивнијих Срба 18. века.

Проучавање књижевног језика војвођанских писаца из 18. века, који су писали, или су се трудили да пишу народним језиком, веома је важно за боље познавање и разумевање развитка српско-хрватског књижевног језика у целини, односно у првом реду његове источне екавске варијанте. Проучавање језика ових писаца, то јест оних чија су дела писана народним језиком, од великог је значаја и за боље познавање и разумевање развитка војвођанских говора, за осветљавање проблема везаних за њихов постанак и развитак и за ближе хронолошко одређивање настанка разних дијалекатских црта. Посматрано у том светлу детаљно испитивање језика војвођанског писца Емануила Јанковића несумњиво је од важности јер је Емануил Јанковић писао готово у потпуности народним језиком, који досада није детаљно проучаван.

Стручњаци који су се бавили до данас Емануилом Јанковићем поклонили су највећу пажњу проблемима везаним за његов живот. ${ }^{1}$ Ако су писали о његовом језику, ограничавали су се само на напомене о његовим делимично спроведеним поступцима у реформисању српске ћирилице. У ствари само наш колега професор Младеновић је писао нешто конкретно о његовом језику у своме чланку Однос између домаћих и рускословенских елемената у књижевном језику код Срба после његове вуковске стандардизације. ${ }^{2}$ За ово проучавање било је узето у обзир по једно штампано дело од три писца, Павла Јелинца, Захарија Орфелина и Ема-

1 Б. Маринковић, Литература о српским писцима XVIII столећа. Биографско-библиографски подаци о Емануилу Јанковићу (1758?-1791), писцу, преводиоцу, књижару и издавачу у Новом Саду, Зборник за историју, св. 45, 1972, 187-208.

2 Зборник за филологију и лингвистику, књ. ХІІ, Нови Сад, 1969, 43-51. 
нуила Јанковића, при чему је детаљно испитан узајмни однос употребе 17 језичких особина које се различито манифестују у српскохрватском и рускословенском језику. Приликом овог испитивања узето је по 40 страна из сваке књиге. Наравно, изнесеним језичким цртама не исцрпљује се списак особина типичних за српскохрватски односно за рускословенски језик. У ствари поменути број особина је довољан за сагледавање како самог проблема тако и извесних решења, али чланак репрезентује само почетна испитивања а не исцрпно испитивање језика ових писаца. У моме раду ${ }^{3}$ Јанковићев језик разматран је у неколико праваца. Прво, извршене су детаљне језичке паралеле између Јанковића и његових савременика у Војводини, Доситеја Обрадовића, Захарија Орфелина, Јована Рајића, Јована Мушкатировића и других писаца. То је исто учињено, разуме се не сасвим доследно, и између Јанковићевог језика и језика његових савременика са запада из Славоније, Босне и Далмације. Успостављен је однос и према језику Гаврила Стефановића Венцловића, представника српскословенског језика у Војводини прве половине XVIII века и према језику војвођанских писаца XIX века, Милована Видаковића, Давида Милошевића и Бранка Радичевића. Друго, Јанковићев језик испитиван је и поређењем са савременим војвођанским говорима, првенствено са говорима Бачке и Срема. Треће, Јанковићев језик је посматран и кроз паралеле према савременом књижевном језику. Извршена су и поређења Јанковићевог језика са Вуковим на основу новијих радова о Вуковом језику. Већ су испитане исцрпно графијске, фонетске, морфолошке и синтаксичке особине у свим Јанковићевим делима и сада обрађујем његову лексику. Све што кажем сада на основу је ових испитивања.

Ја нећу да се задржавам овде детаљно на животу Емануила Јанковића, али да видимо какав је он био човек и за оријентацију оних који ништа или мало знају о њему навешћу неколико основних података. Јанковић је рођен у Новом Саду 1758. О његовим раним годинама у ствари ништа не знамо. 1786. отпутовао је у Немачку, где је на универзитету у Халеу слушао медицину. У Немачкој се бавио научним радом и 1788. природњачко друштво у Халеу изабрало га је за свог члана. Упознао се са Доситејем Обрадовићем и генералом Зорићем, који га је позвао, као и Доситеја, у Шклов у Белорусији за професора физике и математике, али Јанковић се на позив није одазвао. На повратку из Немачке зауставио се у Прагу, где је практично изучавао штампарски занат у једној књижарској радњи и 1790. вратио се у Нови Сад са штампаријом набављеном у Лајпцигу. У Новом Саду обратио се бечком двору преко Конгрегације

${ }^{3}$ Докторска дисертација Кюижевни језик Емануила Јанковића. 
Бачке жупаније са молбом за оснивање српске штампарије, али није добио привилегију. На почетку исте године градски магистрат дозволио му је да отвори књижару, што је одмах и учинио. Иако привилегију за штампање српских књига није добио, ипак је штампао неке ствари на немачком и латинском језику. После тога Јанковић није дуго живео. Још као млад човек у тридесет и трећој својој години умро је 1791. у Суботици. ${ }^{4}$

Његов књижевни рад може се праведно назвати револуционарним за то доба. За свог живота Јанковић је радио на лепој књижевности и науци. Писао је расправе о физичким законима, о филозофији и о логици и превео је неколико позоришних комада са италијанског и немачког језика. У ствари он важи за најбољег преводиоца у XVIII веку. Од његових списа су остала само 4 штампана дела писана током 3 године - једна расправа о физици „Физическоје сочиненије” и три његова превода - „Трговци” са италијанског и „Зао отац” и „Благодарни син” са немачког језика. ${ }^{5}$ Остала је такође једна његова молбеница. ${ }^{6}$ За нас су његови преводи особито важни, јер репрезентују говорни језик у књижевности. У таквим делима има више могућности за употребу простонародног језика.

Његово је време било доба јозефинизма, толеранције и већ изборених и стечених политичких и друштвених права. Он је био велики поклоник Јосифа II, као и Доситеј, као Јован Мушкатировић и други, па је с тих позиција и деловао. Његове идеје о језику биле су плод његовог просветитељског става. Он је знао да народ мора да има књижевност на своме језику. Вођен својим здравим разумом и јаком жељом да уради нешто у корист свог народа, он је готово исто онако убедљиво као касније Вук пропагирао права народног језика у књижевности у предговорима и посветама својих књига. У предговору свог првог превода он се одлучно изјашњава за народни језик - „А што нисам писао у славенским нег у материним језику, то ће ми сваки опростити кад помисли да ја нисам Славјанин нег Србљин и да не пишем за Славјане нег за Србље.” Исто одлучно он се изјашњава за матерњи језик у предговорима своје друге и треће књиге, и у четвртој књизи, мада нема посвете или предговора, ми видимо опет његов став према језику у књижевности у наслову. Наслов је књиге „Благодарни син - Сеоска весела игра стављена на просто српски”.

${ }^{4}$ Б. Маринковић, Емануил Јанковић с оне стране непознатог, Годишғьк $Ф и$ лозобског факултета у Новом Саду, књ. XIV/1 (1971), 191-300 (скраћено: Маринковић, Јанковић).

${ }^{5}$ Г. Михаиловић, Српска библиограбија XVIII века, Београд, 1964, 181-3, 207-8, 210-11

${ }^{6}$ Маринковић, Јанковић, 291-6.

7 Терговичи, Лајпциг, 1787, 4. 
У погледу чистоте језика којим је писао, Јанковић није беспрекоран. Његов језик није чист од рускословенског утицаја, у њему се наилази понекад на поједине форме, речи и реченице, које су против српскохрватског језика како га ми данас схватамо. Ипак овај рускословенски утицај је много скромнијег обима него код његових савременика, укључујући Доситеја. У неким категоријама на фонетском и морфолошком плану уопште нема рускословенског утицаја иако се овај утицај налази у овим категоријама код других писаца. У погледу чистоте језика Јанковић у ствари, као и Доситеј, представља преломну појаву овог периода, скретницу по којој почиње одсудни заокрет на путу литературног језика. Ова значајна прекретница не састоји се само у израженој Јанковићевој жељи да пише народним језиком јер се по томе Јанковић не би одсудно одвајао од других писаца одговарајућег времена. Његова је заслуга то што кад је народни језик био забачен и презрен у лепој књижевности и кад се све хтело писати црквеним језиком, он као следбеник Доситеја, не само што је изнео начело да треба писати лепу књижевност матерњим језиком (то јест простим народним) него је то и учинио, и то успешно.

У употреби народног језика није било ништа револуционарно ни оригинално. Пре њега и у његово време, било је људи који су то чинили (на пример Гаврило Венцловић, Захарије Орфелин, Јован Рајић и сам Доситеј). ${ }^{8}$ Али има разлика између Јанковића и Доситеја с једне стране, и писаца као Венцловић, Орфелин и Јован Рајић с друге. Истина, ови су писци писали дела на народном језику, али то у сваком случају представља само део њихове књижевне делатности, и то мање-више онај део који се не одликује нарочитим књижевним (литерарним) претензијама. За Венцловића српски народни језик остаје само говорни идиом у опреци са црквенословенским језиком, који је једини језик писани и књижевни. Он је писао народним језиком само делове текста којима се обраћа сељацима. ${ }^{9}$ Захарије Орфелин је тражио да се и народни језик употребљава у књижевности, али иако је први прокламовао право народног језика, и сам се много више служио рускословенским језиком, и у томе питању

8 В. С. Јовановић, Гаврило Стефановић Венцловић, Српски дијалектолошки зборник, књ. II, Београд, 1911 (скраћено: Јовановић, Вениловић); А. Младеновић, О народном језику Јована Рајића, Нови Сад, 1964 (скраћено: Младеновић, Рајић); А. Младеновић, Прилог проучавању Орфелиновог језика, Зборник за филологију и тингвистику, књ. III, Нови Сад, 1960, 153-74 (скраћено: Младеновић, Орфелин); Х. Куна, Језичке карактеристике кюижевних дјела Доситеја Обрадовића, Дјела АНУ БиХ, књ. XXXVI, Одјељење друштвених наука, књ. 21, Сарајево, 1970 (скраћено: Куна, Доситеј).

9 Јовановић, Вениловић, 113. 
није био одлучан. У своме „Славено-сербском Магазину” (1768) написао је неке чланке готово чистим рускословенским језиком или руским језиком тог времена нешто пословењеним - то су чланци за образованију публику а друге чланке које је писао за ширу публику он је (како је говорио) „по сербски управљао”, и тиме заправо створио мешавину српског и црквено-руског. Тако се у ствари Орфелин може сматрати творцем славено-српског језика. ${ }^{10}$ Налазимо исти дуализам код Јована Рајића. За Рајића рускословенски језик био је најчистији словенски језик и за све Словене најразумљивији. Зато је требало њега употребљавати као књижевни језик. С друге стране Рајић је сматрао да за просвећивање народа треба писати народним језиком, у чему га треба сматрати заступником Венцловићевих и Орфелинових идеја. ${ }^{11}$

Код Јанковића не налазимо овај лингвистички дуализам. За њега као и за Доситеја нема другог књижевног језика сем матерњег, говорног српског.

Да бисмо разумели његово остварење, потребно је сагледати Јанковићев лик у времену и простору војвођанског XVIII века, прожетог рускословенским језиком, традицијом и уверењем да је једини спас војвођанских Срба наслањање на Русију. Ово је било време јачег литерарног размаха, али истовремено и доба великог језичког шаренила када напоредо егзистирају најразличитији стилови језика. Била је извршена на известан начин дистрибуција стилова према садржају, а донекле према намени књижевног производа, али у ствари стил литерарног језика често је зависио од степена пишчеве образованости. До појаве Доситеја и Јанковића рускословенски или пословењени руски или славено-српски били су доминантни језици у лепој књижевности. ${ }^{12}$

Сагледавано у склопу свих поменутих околности, Јанковићево деловање добива нове димензије, и само узимајући у обзир читаву констелацију тадашње књижевности у погледу језика може се одредити не само вредност Јанковићевог дела него и квалитетна новина његових језичких интервенција. По свом схватању улоге народног језика у лепој књижевности и Јанковић је направио одлучан продор у кулу пословењеног и русифицираног језика своје епохе. Његове су просветитељске амбиције наметале изразито утилитаристички став према књижевности уопште и доследно томе и према језику те књижевности.

10 Б. Николић (приређивач), О језику и књижевности (Сабрана дела Вука Караџића, књ. ХІІ), Београд, 1968, 260.

11 А. Белић, Борба око нашег књижевног језика и правописа, Београд, 1935, 10.

12 B. Unbegaun, Les Débuts de la langue littéraire chez les Serbes, Paris, 1935. 
На темељу материјала који сам анализирао, могу се извући општи закључци о језику Јанковићевих дела, како у погледу односа тог језика према језику литерарних дела његових савременика, тако и на релацији према српскохрватском народном језику и говорима Војводине. Језичке компоненте Јанковићевог језика дозвољавају да се закључи да је Јанковићев језик у односу према стању у тадашњој војвођанској књижевности изразито народни. Већина дијалекатских црта представљају, што се војвођанских говора тиче, у првом реду одлике данашњих бачких говора, ${ }^{13}$ што је у складу са Јанковићевим пореклом, нпр.

(1) Икавизми: где, гдигод, свагди, (у)гријати, угријавати, гријота, посијати, у...коли, наколени, нико, ника, ники, николико, видити, живити, врити, приплакати, привара, призрети (при-, пре-) и тако даље;

(2) место исконскога 'u' стоји 'e' у именици 'колеба';

(3) глаголи 'волети', 'болети' имају презентску основу на 'e' према инфинитиву: волем, воле, да се разболете;

(4) група -ае- ван акцента прелази у дифтонг - $а и$ - код бројева: дванајст, тринајст, итд.;

(5) колебање крајњег вокалског елемента у 'унутра', које се јавља и као 'унутри';

(6) вок. једн. 'duјете';

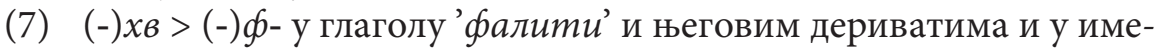
ници 'фбат';

(8) проширење 'o-' у инстр. једнине заменице 'maj', али само у вези с предлогом ' $c$ ': с отим;

(9) код итеративних глагола од простог правила' '-вљь- >-љь-: упраљьати;

(10) група 'мн' дисимилује се: млого, млоги;

(11) (a) $x>\varnothing$ на почетку, у средини и на крају речи: оћy, тео, ладна, леб, ниов, меурови, усане, сирома, стра, пра итд. (б) $x>8$, и у хијату: куварка, куватее, уво, сув, дијати;

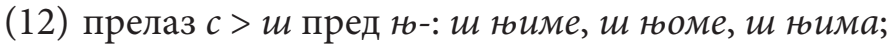

(13) изговор Шлавонија;

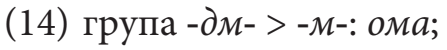

(15) у дат./лок. једн. именице на '- $a$ ' са основом на веларни сугласник задржавају тај сугласник пред наставком -u: $y$ банки, у бриги, у книги, на ноги, итд.;

13 В. И. Поповић, Говор Госпођинаца у светлости бачких говора као иелине (Српска академија наука и уметности. Посебна издања, CDXXV, Одељење литературе и језика, књ. XXI), Београд, 1968. 
(16) чување старих наставака у инстр. и лок. мн. м. и ср. рода: на теђи, с парасници, с послови, у страни језици, рамени, колени;

(17) употреба архаичног наставка '-a' у лок. мн. именица ж. р. на '-a': по кафана, у школа, у земль;

(18) у дат./лок. једн. м. и ср. рода заменичко-придевске промене честа појава -им: о овим посли, у невальалим друству;

(19) у инстр./лок. мн. заменичко-придевске промене постоји наставак'-и' (поред -им(а)): у најлепши коли, с твоји родитељи;

(20) честа појава '-ива' у презентској основи глагола на '-ивати': указива, очекивају, исплаћивају, увређивате;

(21) редовни облици 3. лице мн.: ћеду, можеду;

(22) глаголски облици: метути/метем; иилати/шилем; растати/растио;

(23) прелаз глагола типа 'променити, оканити се' у тип променути, оканути се;

(24) у презентској основи глагола 'гледати' поред 'гледа' јавља се 'гледи', али у инфинитивној основи увек 'гледати' никад 'гледити';

(25) код глагола 'стајати' јавља се у инфинитивној основи напоредо 'сто-' и '-ста';

(26) за означавање футура екзактног употребљава се презент несвршених глагола са префиксом уз: узвиде, усте, узузима, усплаћате, узједеш, узгледа;

(27) заменице се 'таки, оваки' и сл. одликују непознавањем форманта '-в-' док 'какав, -ква' (са сложеним заменицама) има тај елеменат;

(28) именице са старим наставком -ьje прелазе у множину: свећa (ном. мн.);

(29) плуралски облик 'Србљи';

(30) форме као 'каде, саде, полак, нег (< него), итд.

Поређење Јанковићевог језика са језиком писаца који су стварали у приближно исто време (крајем 18. и почетком 19. века, а чији је језик већ испитан, бар делимично) износи на видело подударање у низу појединости као и постојање одређених разлика. Постојање подударања сасвим је разумљиво када се има у виду да су сви ови писци живели у истом и релативно кратком временском раздобљу, онда се мора водити рачуна о различитим дијалекатским основама језика писаца о којима је реч. Не сме се губити из вида на пример Доситејево источнобанатско и Рајићево источносремско порекло итд. Ипак има разлика између Јанковићевог језика и језика других писаца и две следеће разлике су најфрапантније: 
1. Код Јанковића налазимо више доследности како у употреби одређених дијалекатских црта тако и у употреби неких особина карактеристичних за савремени књижевни језик.

2. За разлику од осталих писаца његовог времена на фонетском и морфолошком плану рускословенски утицај је готово незнатан и у многим категоријама, где га налазимо код других писаца, изостаје.

Овде ја не могу описати Јанковићев језик опширно и нисам хтео преоптеретити реферат језичким детаљима и примерима. Ипак, ја бих хтео на крају да наведем неке конкретне примере који ће илустрирати две напред поменуте фрапантне разлике.

У вези са 1. следеће су дијалекатске црте доследне код Јанковића:

(а) икавизми: гди, гдигод, свагди, (у)гриј(ав)ати, гријота, посијати, нико, ники, ника, николико, видити, живити, врити, (пре)трпити, итд. (свега један изузетак: претрпети). Код свих других писаца налазимо више флуктуације или само књижевне форме напр.:

J. Рајић: гди/гдъ, видити/видъти; нъки/нъка, неко/нъколико.

Д. Обрадовић: гди/гдъ, гријати/грејати, видити/видети, нъки, нека, неко, неколико.

М. Видаковић: гди/где, живити/живети, съдити/съдети, нъки, нъко, нъколико/неколико.

J. Мушкатировић: гди/гдъ, гријота, сгрејати, неколико/нъколико/николико. ${ }^{14}$

б) метути/метем, шиљати/шиљем. Доситеј, Ј. Рајић и Мушкатировић имају напредне форме метнути/метнем, метути/метем. Доситеј и J. Рајић имају такође напоредне форме щалем/ шиљем. ${ }^{15}$

(в) именица 'колеба'. Код Видаковића налазимо колебање у употреби $u$ и е: колеба/колиба. Доситеј има само књижевну форму колиба. ${ }^{16}$

${ }_{14}$ Младеновић, Рајић, 60-62, Куна. Доситеј, 59-61; Ј. Кашић, Језик Милована Видаковића, Нови Сад, 1968, 42-4 (скраћено: Кашић, Видаковић); А. Албин, Језик Јована Мушкатировића, Зборник за филологију и лингвистику, књ. ХІІ, Нови Сад, 1969, 55-6 (скраћено: Албин, Мушкатировић).

15 Младеновић, Рајић, 64, 78-9; Куна, Доситеј, 84, 134; Албин, Мушкатировић, 59.

16 Куна, Доситеј, 62; Кашић, Видаковић, 46. 
(г) $и$ ғим(е), ши ғоме, ш ғима. Код Доситеја и С. Новаковића налазимо флуктуацију: ш ғоме / с ғоме, ш ғим(а) / с ғим(а), док Ј. Рајић и Орфелин имају форме без асимилације: $c$ ғимм(a) итд. ${ }^{17}$

(д) $\mathcal{M H}$ - мл- у корену мног- у формама млоги, млого (свега 3 изузетка). Код Доситеја, Мушкатировића, Новаковића и Текелије срећу се напоредне форме: много/млого, многи/млоги. ${ }^{18}$

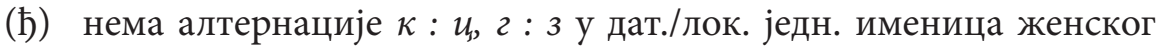
рода на -а. (један изузетак: $y$ војсиц. Палатализовање $\kappa$ испред $u$ јавља се доследно само у лексеми ' $р у к а$ '). Код других писаца има више флуктуације, нема код њих такве доследности.

У вези са 1. следеће су књижевне особине доследне код Јанковића.

(a) зависни падежи присвојних заменица мој, твој, свој долазе увек у краћем облику (свега два изузетка - оба у прологу књиге 'Физическоје сочиненије'). Код свих других писаца налазимо и краће и дуже облике.

(б) дат./лок./ген. једн. м. и ср. рода и дат./инстр./лок. мн. заменичко-придевске деклинације јављају се у краћем облику испред именица. Дуже се форме употребљавају само када стоје у самосталној употреби или после именица нпр. мом стариу, добром сриу, другим зверма, нашим очима, у топлим данима али очима нашима, с другима, у жилама мојима, итд. (изузеци су веома ретки - свега седам-осам). Код других писаца не налазимо такву доследност у употреби краћих и дужих облика.

У вези са 2. не налазимо код Јанковића следеће рускословенске фонетске и морфолошке особине, које се јављају фреквентно у делима других писаца тог времена.

(a) предлози со, ко, в.

(б) заменица кто.

(в) корен черн-<-сrn.

(г) форма ч(е)ловек.

(д) редни број вториј.

(ђ) форме као свобода, (о)свободити.

(е) вок. једн. именица $u$ - основе на -e.

17 Куна, Доситеј, 78; А. Албин, Језик Новина Стефана Новаковића (1792-94), Нови Сад, 1968, 37 (скраћено: Албин, Новаковић); Младеновић, Орфелин, 160; Младеновић, Рајuћ, 43.

${ }_{18}$ Куна, Доситеј, 79; Албин, Мушкатировић, 58; Албин, Новаковић, 41; А. Албин, Језик Саве Текелије, Прилози проучаваюу језика, 4, Нови Сад, 1968, 6. 
(ж) ген. мн. именица са наставцима - еj, -ов, ев, $\varnothing$.

(3) наставак -ими у инстр. мн. заменичко-придевске деклинације.

Својим чистим и готово сасвим народним језиком Јанковић стоји над свим писцима свог времена, па чак и над својим учитељем Доситејом Обрадовићем. У језику Јанковић је набацио здраву мисао коју је могао потпуно реализовати само снажан и јак филолошки ум као што је био Вук. Док је Вук еволуирао до потпуности, нешто из самог себе, нешто под утицајем Копитара, Јанковић је умро млад, кад је тек ушао у живот и рад. Ипак улога коју је одиграо Јанковић у стварању новог књижевног језика у предвуковској епоси значајна је и заиста заслужује нашу пажњу. 